\title{
Psycho-demographic Factors and Entrepreneurial Intention Among University Students
}

\author{
Kehinde A. Ojewumi, Dare A. Fagbenro \& Stephen I. Babatunde \\ Obafemi Awolowo University, Ile-Ife, NIGERIA \\ Department of Psychology
}

Received: 12 April 2020 • Accepted: 1 June 2020 • Published Online: 18 June 2020

\begin{abstract}
The study investigated the role of psycho-demographic factors (resilience, locus of control (LOC), perceived social support (PSS), and gender and university type) on entrepreneurial intention (EI) among final year university students (FYUS). A convenience sample of 491 male and female FYUS with age range from 20 to 35 years $(M=25.11$ years, $S D=3.43)$ completed a cross sectional survey that comprised Demographic Information and measures of Resilience, PSS, LOC and Entrepreneurial Intention. The study hypotheses were tested with multiple regression and twoway ANOVA. The result revealed that there was significant joint influence of resilience, LOC and PSS on entrepreneurial intention $(\mathrm{R} 2=0.16, \mathrm{~F}(3,487)=30.68, \mathrm{p}<.05)$. There was no significant interaction effect between gender and university type on $\mathrm{EI}(\mathrm{F}=(1,487)=0.01, \mathrm{p}>.05)$. This study therefore concluded that resilience; LOC and PSS influence EI among FYUS. We therefore recommended that trained psychologists should develop resilience skill and appropriate LOC orientation program which invariably will boost FYUS positive intention towards starting their own business.
\end{abstract}

Keywords: entrepreneurial intention, resilience, locus of control, perceived social support, gender, institution type.

\section{Introduction}

Entrepreneurship has been recognized as a driving force for economic growth for and development in developed and developing economies of the world. In recent time the concept of Entrepreneurship has become an interesting area among academics, government and policy makers (Muhammad, 2012; Kaegon \& Nwogu, 2012). Entrepreneurism exemplifies the establishment and management of a business undertaking for the main aim of financial gain. Ma and Tan (2006) also went ahead to define entrepreneurism as a process involved in the initiation of a business organization that provides products, the establishment of works that aids sustainable economic advancement (Bilić, Prka \& Vidović, 2011). Conversely, an entrepreneurial individual can be regarded as an initiator, an engine, and who is liable for whatever happens (Torre, 2015a). In a real sense, an entrepreneurial individual has the longing to launch a business venture as a means of achieving financially autonomy and contribute to the society. An individual ability to start his or her business is commonly termed entrepreneurship intention in the literature. As stated by Rasli, Khan, Malekitfar and Jabeen (2013), Entrepreneurship intention is regarded as the frame of mind uphold by a person to promote creativeness in a business enterprise. Therefore,

(C) Authors. Terms and conditions of Creative Commons Attribution 4.0 International (CC BY 4.0) apply. Correspondence: Kehinde A. Ojewumi, Obafemi Awolowo University, Department of Psychology, Ile-Ife, Osun state, NIGERIA. E-mail: ojewumikehinde@gmail.com. 
EI can defined as inclination of an individual to execute entrepreneurial action, to be involved in entrepreneurial operation, be independent worker, or to institute innovative undertaking (Dohse \& Walter, 2010). Most times it demands strong courage, determination and the longing to be selfemployed (Zain, Akram \& Ghani, 2010). According to Halis (2013) people become entrepreneurs because they want to become their own boss at work, they want to achieve private needs through the realization of personal goals and decisions. Over the years, entrepreneurial intent has been demonstrated as a key predictor of whether a person will engage in future entrepreneurial action (Reynolds, 2001; Krueger, Reillu \& Carsurd, 2000). Thus, intention serves as the foundation upon which entrepreneurship is built.

The increasing number of unemployment among graduates is one of the major issues confronting Nigeria in recent time. The National Bureau of Statistics (NBS) estimated that the rate of joblessness in Nigeria increased from 14.2 percent in 2016 to 18.8 per cent in 2017. It surged from 14.2 per cent in the fourth quarter (Q4) 2016 to 16.2 per cent in second quarter (Q2) 2017 and 18.8 per cent in the third quarter (Q3) 2017. The proportion of Nigerian citizen that are meant to be working increased from 83.9 million in the second quarter (Q2) to 85.1 million in the third quarter (Q3) of 2017, a difference of 1.2 million in additional workforce. By 2018, about 80\% of the Nigerian youths are without employment while 1opercent are underemployed with 7 out of 10 graduates deemed to be without employment or partly employed (Ayedun \& Ajayi, 2018). From the above statistics it can be seen that graduate unemployment in Nigeria is quite alarming. Thus, the rate of unemployment in Nigeria calls for an immediate rescue and attention and one way through which this unemployment rate can reduce drastically is for youths and adolescent to have EI built into their psychic. To achieve this, then the process of intention has to begin based on the potential entrepreneur's personal desires, values, wants, habits and beliefs Bird (2012).

Empirical studies have investigated many precursors of EI which include self-efficacy and social networks (Ojewumi \& Fagbenro, 2019), gender and self-efficacy (Ojewumi, Oyeleke, Agberotimi \& Adedayo, 2018), entrepreneurship educational support and informal network (Amos, Oluseye \& Bosede 2015), fear of failure and entrepreneurial self-efficacy (ESE) (Okoye 2016). Despite the important findings of these studies, little or no study have investigated the psychological factors (resilience, locus of control, perceived social support) on EI especially among final year students in Osun state, Nigeria. Hence, the need to investigate these variables as it relates to EI remains pertinent.

Resilience is commonly used to explain the capability to rebound or pull through from stress and ability to adjust to distressing situations (Thomas, 2011; Smith, Epstein, Ortiz, Christopher \& Tooley, 2013). As far as Feldmen (2011) is concerned, people who are resilient are well in charge of over their fate no matter the circumstances they find themselves. This may account for why resilient people are prone to handling major adversities more easily than other people. Till this moment, entrepreneurship literature is seeing the notion of resilience as a reaction to a complex or extreme hardship, or as a personality trait, quality or ability of the entrepreneur. It therefore can be said that when an individual do not have the resilience in terms of capacity to cope and adjust well with stress and pressure associated with starting a business such individual might not be predispose to initiate a business undertaking.

Locus of control is mostly bothered with how an individual perceives his/her capabilities "to control life events" (Leone \& Burns 2000). Individuals who are high in internal LOC" suppose that they are competent to be in command of their life occurrences, while individuals that have external LOC perceives that whatever happens to them are the results of external elements i.e. situations they don't have control on, "such as chance, luck or fate and other individuals that affect their performance across a wide spectrum of activities" (Patrick 2005; Shilpa \& Bharathi, 2017). As may be expected, anyone who has internal LOC thinks that his personal exploit determines the results of his behavior (Rotter, 1966). It therefore can be said that in whatsoever way an individual ascribes control over personal events (to themselves) - internal 
or to other uncontrollable events (external) could go a long way to determine if an individual will be predisposed to starting a business of their own.

Perceived social support is another important variable linked with EI. Social support is therefore beliefs and expected assistance and counsel that a person may get from the social groups that he/she belongs (Sahban, Kumar \& Sri Ramalu, 2014). These social groups may comprise primary groups in terms of parents, siblings, and spouses; and at the same time include secondary groups, such as comparison groups like friends, colleagues and teachers. Professionals have categorized social support into three main scopes: support by family; and support by friends/ peer groups; and significant others (Zafar, Yasin \& Ijaz, 2012). Therefore the social support gotten from either friend, family and significant others could determine if an individual will want to start a business.

Apart from the psychological variables considered in this study, the role of sociodemographic factors such as gender and university type has been jointly given less attention in the literature. Thus, understanding gender and university type interactions may help proffer genderinstitution intervention to FYUS on the required skill that can boost their EI. Hence this particular study also considered the interactive role of gender and university type on EI.

Drawing upon from the Shapero's Model of Entrepreneurial Event, the theory argues that intention formation is as a result of, first, the perceived desirability- that is the fascination for a person to initiate the setting up of a personal business and secondly, the perceived viability- that is, the degree that a person see that he/she can start personal business in the face of opportunities. In this context, it is argued that FYUS who have a strong resilience, better LOC orientation and strong PSS may submit higher EI because these assets may protect him/her against frightening circumstances, helps in improving the management, control and coping with challenges of starting a business. At the same time, they are well grounded to be able to take risk which starting their own personal business entails. It is from this foregoing that this survey examines the role of psycho-demographic factors on EI among final year university students.

2. Review of empirical studies on psychological factors and entrepreneurial intention

Hlatywayo, Marange and Chinyamurindi (2017) examined Psychological capital (PsyCap) in the prediction of EI among 270 undergraduates. Result found that resilience was the lone significant PsyCap concept that contributed distinctive variation in predicting EI. RappRicciardi, Barbieri and Amato, (2018) examined psychopathy, narcissism and Machiavellianism, internal LOC, and positive and negative affect on EI among respondents. The study found that there was joint influence of psychopathy, narcissism and Machiavellianism, internal LOC, and positive and negative affect on EI. Ojiaku, Nkamnebe and Nwaizugbo (2018) investigated variables predicting EI among a sample of 288 National Youth Service Corp members in Anambra State, Southeast Nigeria, The outcome shows that the pull factors in terms of (independence, autonomy, opportunities exploitation) and the mooring variables (i.e., government support, personal attitude, self-efficacy) significantly influence EI with the mooring factors having the most influence on EI. Hermawan, Soetjipto and Rahayu (2016) examine the effect of LOC on entrepreneurship interest. Quantitative research approach with descriptive and explanatory approach was used in the survey. The initial population of study was 622 students from the twelfth grades. However, using a proportional random sampling technique, sample calculation was used to get a sample size of 124. Result showed that student with internal LOC has interest in entrepreneurship than student that possesses external LOC. Ozaralli and Rivenburgh (2016) examined the precursors of EI among 589 Junior and Senior US and Turkey students. The authors established a statistically significant relationship between personality attributes, economic and political conditions and EI. 
Akanbi and Owoseni, (2015) examined innovativeness, risk taking behavior and LOC on EI among 400 students that were selected across a private university faculty. The survey revealed that innovativeness, risk taking behaviour and LOC of an individual influence a person's EI. Ayodele (2013) investigate sex, socio-economic status, and age, LOC, ESE and EI among 210 students from different high schools in Ogun State. Four standardized instruments were used in the study. Results indicate that LOC, ESE, socio-economic status had noteworthy correlation with the adolescents' EI, while age and sex did not influence EI. Ngwoke, Oyeoku and Obikwelu, (2013) examined perceived LOC as a predictor of entrepreneurial development and job creation among 444 students. The study found that students who are high in internal LOC scored higher in entrepreneurial development skills.

Molino, Dolce, Cortese and Ghislieri (2018) investigate the role of personality and PSS as determinants of EI. The result established a significant joint role of personality and PSS on EI among the sampled respondents. Tao Shen, and Osorio (2017) examined family support on entrepreneurial attitudes and intents of college students. The study found that family support has significant influence on entrepreneurial attitudes and intentions. AmsalSahban, Sri Ramalu and Syahputra (2016) investigated the influence of SS on student's inclination toward entrepreneurship. The result affirmed a positive relationship between SS system and student's inclination toward entrepreneurship. Okoye, Audu and Karatu (2017) investigated the role of emotional intelligence and PSS as determinants of entrepreneurial success among One hundred and seventy-four (174) participants. The results show that emotional intelligence and PSS was significantly related with entrepreneurial success among the respondents. Juan, Francisco José and José (2007) in their study found out that PSS have a significant influence on EI. Achchuthan and Nimalathasan (2012) reported that problems in the financial assistance, lack of infrastructure facilities, lack of technological facilities, lack of backup from governmental and non-governmental organisations in the Jaffna district, Sri Lanka, becomes a barrier for potential young entrepreneurs in starting up a new venture. Olufunso (2010) also reported that lack of access to finance, lack of know-how, government assistance, risk and the macro-economy are the obstacles that inhibit graduates who have an intention to launch a successful business in South Africa.

\section{Demographic factors (gender and university type) and entrepreneurial intention}

Chaudhary (2017) revealed no meaningful difference between men and women on entrepreneurial intention. Zeffane (2013) in their research found no difference between males and females on entrepreneurship in United Arab Emirates. Zaidatol and Afsaneh (2009) on their own discovered noteworthy difference in the EI of male and female students with male undergraduates having higher entrepreneurial intention. Brush and Cooper (2012) in their study detected that both men and women entrepreneurs showed very little difference on EI. Omer, Sonal and Vaheed (2017) considered EI among college undergraduates in Oman with the aim of accessing the mindset of out-going undergraduates in Oman towards entrepreneurship. The findings demonstrate that private or public university has no effect on undergraduates' mind-set towards business. Canever, Barral and Ribeiro (2017) investigated the causal connections of various college environments (Public and Private) on the undergraduates' EI. The survey established that Brazilian college situations (public/ private) do not offer much contrasts in ways they impact EI and its precursors. Akinbola, Ogunnaike and Amaihian (2015) in their work centered on the influence of institutional type on EI of university students found that there was an association between EI among final year private and state funded college undergraduates in Lagos and Ogun State, Nigeria. Peprah, Afoakwa and Koomson (2015) posited that savings behavior and entrepreneurial characteristic impact the choice to engage in private business among undergraduates from chosen public and private colleges in Ghana.

Based on the literature reviewed, the following hypotheses were tested: 
(1) There will be a significant joint and independent influence of resilience, locus of control and perceived social support on EI among FYUS.

FYUS.

(2) Gender and university type will have significant interaction effect on EI among

4. Methods

4.1 Design

The study adopted a cross-sectional survey design based on the fact that the study used questionnaire in collecting data on all variables under investigation at different point in time. The independent variables were resilience, LOC, PSS, gender and university type while the dependent variable was EI.

\subsection{Setting}

The study was carried out among final year students of Obafemi Awolowo University (OAU) and Oduduwa University (OUI) all in Ile-Ife Osun state. The justification for the setting is because there is large population of final year university students who are potential entrepreneurs in these two universities.

\subsection{Participants and sampling technique}

A total number of four hundred and ninety-one (491) participated in the study. In terms of gender, $170(34.6 \%)$ and $321(65.4 \%)$ constituted the frequency distribution of male and female respectively. Age of the respondents revealed that 96(19.6\%) of the respondents were between the age of 20-24 years while majority 321 (65.4\%) fall between the age brackets of 2529years, 65(13.2\%) belong to age bracket of 30-34 years and 9(1.8\%) were above 35 years. Proportions of marital status shows that majority 479(97.6\%) of the respondents were single, 12(2.4\%) were married. Religion shows that larger proportion 392(79.8\%) were Christians, 20(20.2\%) were Muslims. socio-economic status reveals that 44 (9\%) of the respondents were from low socio-economic status, majority 390(79.4\%) were from moderate socio-economic status and $57(11.6 \%)$ were from high socio-economic status. Also, the type of institution reveals that 289 (58.9\%) of the respondents were from federal university and 202(41.1\%) were from private university. The study used a purposive sampling to select the setting used for the study while convenience sampling technique was used to select the respondents from the two universities.

\section{Measures}

Entrepreneurial intention was measured with the use of Entrepreneurial Intent Scale (IEI) which was developed by Edmund (2009). The scale was scored in a 5-point Likert scale ranging from $1=$ strongly disagree to $5=$ strongly agree. Possible scores ranged from 16 to 80 . Higher scores indicate that individuals are positively disposed to entrepreneurship intention while lower score indicate that respondents are negatively disposed to entrepreneurship intention. The internal consistency showed a good reliability with Cronbach's alpha of 0.89 .

Resilience was measured with a Brief resilience scale (BRS) developed by Smith, Dalen and Wiggins (2008). The BRS is made up of six items; three negative items and three positive items. According to Smith et al., items 1, 3 and 5 are positively worded while items 2, 4, and 6 are negatively worded. Participants were requested to answer each question by signifying their 
K. A. Ojewumi, D. A. Fagbenro \& S. I. Babatunde - Psycho-demograhic Factors and Entrepreneurial...

agreement with each statement using the 5 point Likert scale ranging from $1=$ strongly disagree, to $5=$ strongly agree. The BRS demonstrated good internal consistency with the value of Cronbach's alpha ranging from .80- .91. Convergent validity and discriminant predictive validity were also reported by Smith et al. (2008) as part of the validation analysis.

Locus of Control was evaluated with the 20-item true/false Locus of Control Scale developed by Pettijohn (1992). Each response of the 20 item is scored as o or 5, so the test can range from $\mathrm{O}=$ very strong external locus of control to $100=$ very strong internal LOC. Form the sample, the mean rotter score was $10.4(\mathrm{SD}=3.6$ range $0-20)$ and that for the score was $70.9(\mathrm{SD}=$ 10.9 range 40-60). The Cronbach value for internal consistency, alpha was .43

Perceived Social Support was assessed with a 12 items MSPSS (Multidimensional Scale of Perceived Social Support) devised by Zimet, Gregory, Dahlem, Nancy, Zimet, Sara, Farley and Gordon (1988). The scale measures the degree to which a person discern SS from family, friends and significant others. The MSPSS is a brief, easy to handle self-report questionnaire which contains 12 items rated on a 7-point Likert scale ranging from "very strongly disagree" (1) to "very strongly agree' (7). The MSPSS has proven to be psychometrically sound in diverse samples and to have good internal reliability and test-retest reliability, and robust factorial validity. Cronbach alpha obtained for the Family, friends, and significant other, subscales were .90, .94, and .95 respectively. The reliability of the whole scale was .91. These values indicate a good internal consistency for the scale as a whole and for the three subscales individually. The norm for this scale was established among 154 people with mean age=26.5 years, $\mathrm{SD}=7.4$.

\section{Method of data collection}

Questionnaires were administered to students during their lecture free time at their various faculties. All participants were duly informed of the reason for the study and equally provided written consent form. The researcher explained the rationale and importance of the study to the participants. At the point of meeting with the students, they were made to know that their names are not required on the questionnaires, moreover, that information supplied will only be used for research purpose. The principle of research ethics was strictly adhered to by the researcher. This was achieved when the participants were informed that the research will not expose them to any physical, psychological, or emotional harm. A total number of 250 questionnaires each was distributed across the two universities totaling about 500 copies of questionnaires but only 491 was retrieved and used for data analyses.

\section{Statistical analysis}

Data was analyzed with the use of descriptive and inferential statistic using Statistical Package for Social Sciences (SPSS) Version 20. Descriptive statistics was used to analyze the socio demographic factors of the participants while inferential statistics was used to test the hypotheses in the study. Hypothesis one was tested using multiple regression analysis while hypothesis two was examined using two-way ANOVA all at 0.05 level of significance.

\section{Results}

\subsection{Hypothesis One}

There will be joint and independent role of psychological factors (Resilience, LOC and PSS) on EI among FYUS. The results are presented in Table 1. 
Table 1. Summary of multiple regression analysis showing the influence of resilience, locus of control and social support on entrepreneurial intention

\begin{tabular}{lccccccc}
\hline Predictors & $\mathbf{B}$ & $\mathbf{t}$ & $\mathbf{P}$ & $\boldsymbol{R}$ & $\boldsymbol{R}^{\mathbf{2}}$ & $\boldsymbol{F}$ & $\boldsymbol{P}$ \\
\hline Resilience & .23 & 5.39 & $<.05$ & & & & \\
Locus of control & .10 & 2.32 & $<.05$ & .40 & .16 & 30.68 & $<.05$ \\
Social support & .24 & 5.28 & $<.05$ & & & & \\
\hline
\end{tabular}

The result revealed that resilience, LOC and PSS have jointly predicted $\mathrm{EI}\left(\mathrm{R}^{2}=0.16\right.$, $\mathrm{F}(3,487)=30.68, \mathrm{p}<.05)$. When combined, resilience, LOC and PSS explained $16 \%$ of the change observed in the self-report EI. This revealed that the collective presence of resilience, LOC and PSS has significant influence on EI. The result further revealed that resilience $(\beta=.23, t=5.39$, $\mathrm{p}<.05)$, locus of control $(\beta=.10, \mathrm{t}=2.32, \mathrm{p}<.05)$ and social support $(\beta=.24, \mathrm{t}=5.28, \mathrm{p}<.05)$ have significant independent influence on EI. The hypothesis is thus accepted.

\subsection{Hypothesis Two}

Gender and university type will have significant interaction effect' on EI. This was tested using 2x2 ANOVA and the outcome displayed in Table 2.

Table 2. Summary of 2x2 ANOVA showing the role of gender and university type on entrepreneurial intention

\begin{tabular}{lccccc}
\hline Source & $\begin{array}{l}\text { Type III Sum of } \\
\text { Squares }\end{array}$ & df & Mean Square & F & Sig. \\
\hline Gender & 72.148 & 1 & 72.148 & 1.766 & $>.05$ \\
University type & 9.157 & 1 & 9.157 & .224 & $>.05$ \\
Gender * university type & .262 & 1 & .262 & .006 & $>.05$ \\
Error & 19895.207 & 487 & 40.853 & & \\
Corrected Total & 19976.969 & 490 & & & \\
\hline
\end{tabular}

The result of the hypothesis shows that there was no main effect of gender $(\mathrm{F}(1,487)$ $=1.77, \mathrm{p}>.05)$ on EI. There was also no significant main effect of university type on EI $(\mathrm{F}(1,487)$ $=0.22, \mathrm{p}>.05)$. Furthermore, the result also discovered no significant interaction between gender and university type on EI $(F=(1,487)=0.01, p>.05)$. The stated hypothesis was rejected.

\section{Discussion}

The study considered the role of psychological variables (resilience, locus of control and social support) on EI among FYUS. Based on the first hypothesis postulated in the study, it was found that there was a joint influence of resilience, LOC and PSS on EI among FYUS. The study finding was in accordance with Hlatywayo, Marange and Chinyamurindi (2017) where they found that resilience was the lone significant Psychological capital concept that contributed distinctive variation in predicting EI. The study was also in line with Ojiaku, Nkamnebe and Nwaizugbo (2018) who found that mooring variables (i.e., government support) significantly influence EI. At the same time, the findings was also in accordance with findings of Ngwoke, Oyeoku and Obikwelu, (2013) that found that students who possess an internal LOC have better entrepreneurial development skills. The reason for this could be that in Nigeria of today, personal resources such as resilience and proper LOC orientation is needed as a personal resource in other to strive well in business, coupled with a good social support foundation which invariably could encourage individual to develop positive intention towards the establishment of personal business. 
The second hypothesis affirmed that there was no interaction between gender and university type on EI. The finding was in agreement with the result of the study done by Chaudhary (2017) that revealed no meaningful differences between men and women on EI. Also, Zeffane (2013) in their research found no difference between males and females on entrepreneurship in United Arab Emirates. On the contrary, the study was not in line with the submission of Akinbola, Ogunnaike and Amaihian (2015) in their work centered on the influence of institution type on EI of university students. The study found that there was association between EI among final year university students in private and state funded colleges. The justification of the result maybe unconnected with the fact that in Nigeria; both male and female students who attended either private or public universities are both faced with the challenge of unemployment which did not differentiate on the basis of university attended and therefore no difference in their EI.

\section{Conclusion}

Based on the findings of the survey, we determined that there was joint and independent influence of psychological factors (resilience, LOC and social support) on EI among FYUS. Finally, it was also concluded that there was no influence of demographic factors on EI among final year university students.

\section{Implication and recommendations of the study}

The study has been able to find out that resilience, LOC and PSS influence EI among final year university students. This result therefore implies that concerned stakeholders must take cognizance of these variables if FYUS are to have any inclination of engaging in their own individual business. Theoretically, this study also has implication for Shapero's Model of Entrepreneurial Event by building on the theory through the incorporation of resilience, LOC and PSS as an important personal and external characteristic which can explain variance in EI among students. The study consequently advocates that university decision-makers should employ trained psychologists in collaboration should develop resilience skill and appropriate locus of control orientation programs which invariably will boost FYUS toward having a favorable intention of starting their own business. Policy makers should introduce social support programs in form of entrepreneurial events, educational workshops as well as loans, grant etc. for all FYUS who are interested in setting up private business, moreover, friends and family could also support these potential entrepreneur either financially or otherwise, such that this would serve as an encouragement toward starting their own business.

\section{Limitation and suggestion for future directions}

Empirical study is without its limitation, this study stands in that direction. Firstly, generalization of research finding to other setting is a major limitation in this study; this is because the study only used two universities from a relatively few sample of students in Osun state therefore generalizing the research findings to other universities in Nigeria maybe impossible. Another limitation of this study is that causal connection cannot be established. It is therefore suggested that future studies should be expanded to explore the scope of this study by investigating FYUS from different universities across the states in Nigeria. It is also suggested that future study should incorporate qualitative method of data collection such as interview; focus group discussion etc. for better validation of research finding. Finally, more psychosocial variables such as need for achievement, perceived competence etc. should be investigated on EI among students. 


\section{Acknowledgements}

This research did not receive any specific grant from funding agencies in the public commercial, or not-for-profit sectors.

The authors declare no competing interests.

\section{References}

Achchuthan, S., \& Nimalathasan, B. (2012). Level of entrepreneurial intention of the management undergraduates in the university of Jaffna, Sri Lanka: Scholars and undergraduates perspective: South Asian Academic Research Journals, 2(10), 24-42.

Akanbi, P., \& Owoseni, O. (2015). Influence of personality traits on entrepreneurial intentions. An article published in the Department of Business Administration, Ajayi Crowther University, Oyo, Nigeria.

Akinbola, O. A., Ogunnaike, O. O., \& Amaihian, A. B. (2015). Influence of contextual factors on entrepreneurial intention of university students: The Nigerian experience. Journal of South African Business Research, 3(2), 13-34.

Amos, A., Oluseye, O., \& Bosede, A. (2015). Influence of contextual factors on entrepreneurial intention of university students: The Nigerian experience. Journal of South African Business Research, 6, 2- 10. https://doi.org/10.5171/2015.750622

AmsalSahban, M., Sri Ramalu, S., \& Syahputra, R. (2016). The influence of social support on entrepreneurial inclination among business students in Indonesia. Journal of management, 12, 45-67.

Ayedun, A., \& Ajayi, O. (2018). Entrepreneurial intention among students of selected tertiary institutions in Ondo State. International Journal of Development Strategies in Humanities, Management and Social Sciences, 8(1), 1-16.

Ayodele, K. O. (2013). Demographics, entrepreneurial self-efficacy and locus of control as determinants of adolescents' entrepreneurial. European Journal of Business and Social Sciences, 1(12), 59-67.

Bilić, I., Prka, A., \& Vidović, G. (2011). How does education influence entrepreneurship orientation? Case study of Croatia. Management, 16(1), 115-128.

Brush, C. G., \& Cooper, S. Y. (2012). Female entrepreneurship and economic development: An international perspective. Entrepreneurship \& Regional Development, 24(1), 1-6.

Canever, D., Barral, M., \& Ribeiro, G. (2017). How does the public and private university environment affect students' entrepreneurial intention? Education and Training, 9(6), 3-5

Chaudhary, R. (2017) Demographic factors, personality and entrepreneurial inclination: A study among Indian university students. Education Training, 59, 171-187. https://doi.org/10.1108/ET-022016-0024

Dohse, D., \& Walter, S. G. (2010). The role of entrepreneurship education and regional context in forming entrepreneurial intentions: Document de treball de l'IEB. www.ent.ut.ac.ir/jger/images/usersfiles/1/file/pdf/kim\%20kliver\%201.pdf.

Feldman, R. S. (2011). Understanding psychology (10 ${ }^{\text {th }}$ Ed). New York: McGraw-Hill.

Francisco, P., José, T., \& José, E. (2007). The impact of entrepreneurship education on entrepreneurial selfefficacy. International Journal of Entrepreneurship Education, 1, 2-8. 
K. A. Ojewumi, D. A. Fagbenro \& S. I. Babatunde - Psycho-demograhic Factors and Entrepreneurial...

Halis, L. (2013). Born to be an entrepreneur? Revisiting the personality approach to entrepreneurship. Psychology Entrepreneur, 4, 165-172.

Hermawan, R., Soetjipto, B., \& Rahayu, W. (2016). Effect of locus of control on entrepreneurship interest through entrepreneurship literacy. Journal of Business and Management, 18(2), 141-148.

Hlatywayo, C. K., Marange, C. S., \& Chinyamurindi, W. T. (2017). A hierarchical multiple regression approach on determining the effect of psychological capital on entrepreneurial intention. Journal of management science, 14, 12-21.

Kaegon L. E., \& Nwogu U. J. (2012). Entrepreneurship education in Nigerian universities: A panacea for unemployment in Nigeria. British Journal of Advance Academic Research, 1(1), 57-67.

Krueger, N. F. Jr., Reilly, M. D., \& Carsrud, A. L. (2000). Competing model of entrepreneurial intentions. Journal of Business Venturing, 15(5-6), 411-432.

Leone, C. \& Burns, J. (2000). The measurement of locus of control: assessing more than meets the eye? The Journal of Psychology, 134(1), 63-76.

Ma, H., \& Tan, J. (2006). Key components implications of entrepreneurship: A 4-p framework. Journal Business Venturing, 21(5), 704-725.

Molino, M., Dolce, V., Cortese, C. G., \& Ghislieri, C. (2018). Personality and social support as determinants of entrepreneurial intention. Gender differences in Italy. PLOS ONE, 13(6), e0199924. https://doi.org/10.1371/journal.pone.0199924

Muhammad, D. A. (2012). Entrepreneurial intention among undergraduate students in International Islamic University Malaysia-IIUM: A paper presented at the $6^{\text {th }}$ Islamic Development Management Conference (IDMAC, 2012). University of Sains, Malaysia.

Ngwoke, D., Oyeoku, E., \& Obikwelu, L. (2013). Perceived locus of control as a predictor of entrepreneurial development and job creation among students in the tertiary. Journal of Education and Practice, 4, 14-32.

Ojewumi, A., \& Fagbenro, D. (2019). Entrepreneurial intention among polytechnic students in Nigeria: the role of self- efficacy and social networks. International Journal of Entrepreneurial Knowledge, 7(1), 20-30.

Ojewumi, A., Oyeleke, J., Agberotimi, F., \& Adedayo, O. (2018). The influence of gender and self-efficacy on entrepreneurial intentions among Obafemi Awolowo University Undergraduate Students. Africology: The Journal of Pan African Studies, 11(2), 169-185.

Ojiaku, C., Nkamnebe, D., \& Nwaizugbo, C. (2018). Determinants of entrepreneurial intentions among young graduates: perspectives of push-pull-mooring model. Journal of Global Entrepreneurship Research, 8, 24-32.

Okoye, J. (2016). Psychosocial predictors of entrepreneurial intention among Nigerian graduates. International Journal of Psychology and Counselling, 8(6), 73-80. https://doi.org/10.5897/IJPC2016.0407

Okoye, J., Audu, U., \& Karatu, E. (2017). Emotional intelligence and social support as determinants of entrepreneurial success among business owners in Onitsha metropolis, Nigeria European Journal of Research in Social Sciences, 5(3), 37-47.

Olufunso, O. F. (2010). Graduate entrepreneurial intention in South Africa: Motivation and obstacles. International Journal of Business and Management, 5(9), 87-98.

Omer, A. I., Sonal, D., \& Vaheed, U. (2017). Implication of attitude of graduate students in Oman towards entrepreneurship: An empirical study. Journal of Global Entrepreneurship Research, 2, 5776.

Ozaralli, N., \& Rivenburgh, K. (2016). Entrepreneurial intention: antecedents to entrepreneurial behavior in the U.S.A. and Turkey. Journal of Global Entrepreneurship Research, 6(3). https://doi.org/10.1186/s40497-016-0047-x 
Patrick M. (2005). Locus of control and its relation to working life: Studies from the fields of vocational rehabilitation and small of Human Work Sciences. Technical Psychology, 13(1), 1462-1544

Peprah, J. A., Afoakwah, C., \& Koomson, I. (2015). Savings, entrepreneurial trait and self-employment: Evidence from selected Ghanaian universities. Journal of Entrepreneurship Behaviour, 4, 5667.

Rapp-Ricciardi, M., Barbieri, B., \& Amato, C. (2018). Dark triad, locus of control and affective status among individuals with an entrepreneurial intent. Journal of Entrepreneurship Education, 21(1), 118.

Rasli, A. M., Khan, S. R., Malekitfar, S., \& Jabeen, S. (2013). Factors affecting entrepreneurial intention among graduate. Journal of Managerial Science, 9, 56-65.

Reynolds, P. D. (2001). Global entrepreneurship monitor 2001 executive report. Kauffman Centre for Entrepreneurial Leadership.

Rotter, J. B. (1966). Generalized expectancies for internal versus external locus control of reinforcement. Psychological monographs: General and Applied, Serial Number, 6o9(80), 1-28

Shilpa H. A., \& Bharathi V. S. (2017). Locus of control: Influence of Internality, externality- others, externality-chance among management students. The International Journal of Indian Psychology, 4(2), 94, DIP: 18.01.156/20170402 ISBN: 978-1-365-84229-0.

Smith, B. W., Dalen, J., Wiggins, K., Tooley, E., Christopher, P., \& Bernard, J. (2008). The brief resilience scale: Assessing the ability to bounce back. International Journal of Behavioral Medicine, 15, 194-200. http://dx.doi.org/10.1080/10705500802222972

Smith, B. W., Epstein, E. M., Ortiz, J. A., Christopher, P. J., \& Tooley, E. M. (2013). The foundation of resilience: What are the critical resources for bouncing back from stress? In S. P. Embury \& D. H. Saklofske (Eds.), Resilience in children, adolescent, and adults. Translating research into practice (pp. 167-188). New York: Springer. http://dx.doi.org/10.1007/978-1-4614-4939-3_13

Tao Shen, J., \& Osorio, E. (2017). does family support matter? the influence of support factors on entrepreneurial attitudes and intentions of college students. Academy of Entrepreneurship Journal, 23(1), 24-43.

Thomas, D. A. (2011). Reaching resilience: Protective factors and adult children of divorce. Retrieved from http://counselingoutfitters.com/vistas/vistas11/Article_22.pdf.

Torre, J. J. D. (2015a). Who is an Entrepreneur? Available at: https://www.entrepreneur.com/article/245628.

Zafar, M. J., Yasin, G., \& Ijaz, M. (2012). Social networking as source for developing entrepreneurial intentions among entrepreneurs: A case of Multan. Asian Economic and Financial Review, 2(8), 1072-1084.

Zaidatol, Y., \& Afsaneh, T. (2009). Assessing SME Generation's entrepreneurship degree programmes in Malaysia, Education and Training, 52(6), 508-527.

Zain, Z. M., Akram, A. M., \& Ghani, E. K. (2010). Entrepreneurship intentions among Malaysian business students. Canadian Social Science Journal, 6(3), 34-44.

Zeffane, T. (2013). Opportunity entrepreneurship in the rural sector: Evidence from Greece. Journal of Research in Marketing and Entrepreneurship, 12(2), 122-142.

Zimet, Gregory D., Dahlem, Nancy W., Zimet, Sara G., \& Farley, K. (1988). The multidimensional scale of perceived social support. Journal Personality Assessment, 52(1), 30-41. 
K. A. Ojewumi, D. A. Fagbenro \& S. I. Babatunde - Psycho-demograhic Factors and Entrepreneurial...

\section{Biographical notes:}

Kehinde A. Ojewumi is a lecturer and researcher at the Department of Psychology, Obafemi Awolowo University Ile- Ife, Osun state Nigeria. He has published many articles both locally and internationally in his area of specialization. He has attended several local and international conferences both in Nigeria and outside Nigeria.

Dare A. Fagbenro is a doctoral student in the Department of Psychology, Obafemi Awolowo University Ile-Ife Osun state Nigeria. He is an industrial and organizational psychologist. He is a foundation member of the Nigeria association of industrial and organizational psychologist (NAIOP). His area of interest includes Employee work attitude, workplace behavior and Research Methodology in behavioral science. He has attended several local conferences in Nigeria.

Stephen I. Babatunde is currently a doctoral student at the Obafemi Awolowo University Ile-Ife Osun state, Nigeria. He has attended several conferences in Nigeria. He is also the chairman of postgraduate students under the auspices of the Nigeria Psychological Association (NPA). 